\title{
Visualization Study of Terrorist Groups in the Middle East Based on UCINET
}

\author{
Lingzhi Jiang ${ }^{\mathrm{a}}$, Qiwu Wu ${ }^{\mathrm{b}, *}$ and Mingzhu Zheng ${ }^{\mathrm{c}}$ \\ Engineering University of CAPF, Xi'an, 710086, China \\ "Corresponding author.Email: ${ }^{a}$ ustb520@163.com; ${ }^{b}$ wuqiwu700@163.com; ${ }^{c} 1123722923 @ q q . c o m$
}

\begin{abstract}
At present, with the development of information technology and the international community's efforts to combat terrorism, terrorism is constantly transforming and escalating, taking on the characteristics of Al-Qaida, globalization and networking. Therefore, it is of great significance to study terrorist organizations from the perspective of social network in order to combat terrorist activities. In this paper, we mainly use the social network analysis method to study the relationship network of terrorist organizations in the Middle East, and analyze their network centrality and density with the help of UCINET, so as to get the conclusion about the characteristics of terrorist organizations, and then formulate corresponding counter-terrorism strategies to provide strong theoretical support for the fight against terrorism.
\end{abstract}

Keywords: Social network analysis, UCINET software, Middle East, Centrality, Network density.

\section{INTRODUCTION}

Terrorism, as a special kind of violence, has emerged and developed along with the intensification or deformation of conflicts within and between States in various aspects [1]. Contemporary terrorism has become the most important concern for all countries due to the unimaginable spread of the harm and the consequences of contemporary terrorism. And with the rapid development of social network analysis in the fields of probability, graph theory methods, and statistics, it has shown unique advantages in many fields [2]. Therefore, after 9.11, social network analysis has become a hotspot in the field of counterterrorism [3]. The use of social network analysis can reveal the relationships between terrorist organizations and their characteristics, and provide advice and guidance for preventing and combating terrorism.

\section{MODELING OF TERRORIST NETWORKS IN THE MIDDLE EAST}

\subsection{Research Methodology}

The method used in the study of social relationship networks is social network analysis, which mainly analyzes the structure of the network as well as its characteristics, also known as structural analysis. The theory of anti-terrorism analysis based on social networks not only has the advantages of social network analysis, but also can analyze and study the characteristics and attributes of relational networks with the help of computer technology, so it is widely used in the field of anti-terrorism [4]. Its commonly used analytical indicators are centrality and network density.

\subsection{Data Sources}

The data in this paper is mainly based on the list of terrorist organizations identified by the main national and international organizations in the Yearbook of International Terrorism and the Fight against Terrorism as of 2019[5], which yields the following 103 major terrorist organization numbers in the Middle East. 


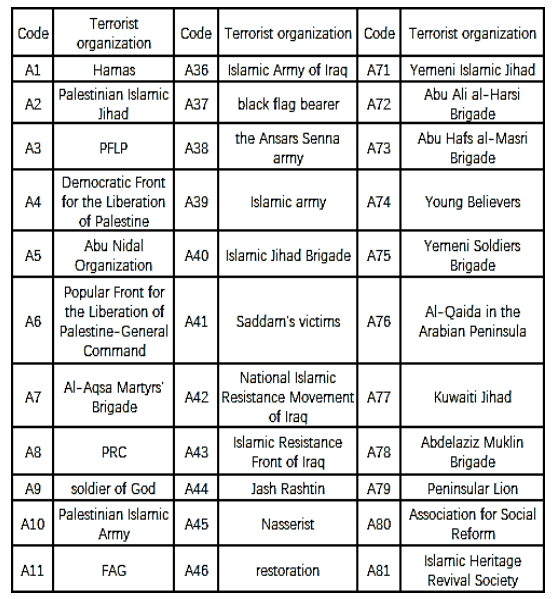

\begin{tabular}{|c|c|c|c|c|c|}
\hline A12 & Imad Mughniyeh & A47 & \begin{tabular}{|c|}
$\begin{array}{c}\text { Armed Pioneers of } \\
\text { the Second } \\
\text { Mohammedan Army }\end{array}$ \\
\end{tabular} & A82 & \begin{tabular}{|l|} 
Islamic Front for the \\
Liberation of Bahrain \\
\end{tabular} \\
\hline $\mathrm{A} 13$ & $\begin{array}{l}\text { thunder and } \\
\text { lightning }\end{array}$ & A48 & $\begin{array}{l}\text { Iraqi Resistance } \\
\text { Brigade }\end{array}$ & A83 & Jewish Federations \\
\hline A14 & Storm Eagle & A49 & Awakening and Jihad & A84 & Kahani Moverment \\
\hline A15 & Ansarzana & A50 & $\begin{array}{c}\text { Abu Daraa } \\
\text { Organization } \\
\end{array}$ & A85 & \begin{tabular}{|c|}
$\begin{array}{c}\text { Union for the Defence } \\
\text { of the lews }\end{array}$ \\
\end{tabular} \\
\hline A16 & \begin{tabular}{c|}
$\begin{array}{c}\text { Egyptian Islamic } \\
\text { Jihad }\end{array}$ \\
\end{tabular} & A51 & \begin{tabular}{|c|} 
lihad and the Course \\
of Reform
\end{tabular} & A86 & PKK \\
\hline A17 & $\begin{array}{c}\text { Islamic } \\
\text { organization }\end{array}$ & A52 & Hamas in Iraq & A87 & Hizb ut-Tahrir \\
\hline A18 & $\begin{array}{c}\text { Atonement and } \\
1 \mathrm{OM}\end{array}$ & A53 & Warrior in Paradise & A88 & RPLP \\
\hline A19 & $\begin{array}{c}\text { Islamic Self- } \\
\text { Respect Brigade of } \\
\text { Egypt }\end{array}$ & A54 & $\begin{array}{l}\text { The Army of the } \\
\text { Nacos Bandian } \\
\text { Cormmander }\end{array}$ & A89 & FIO \\
\hline A20 & $\begin{array}{c}\text { Abdullah Azzam } \\
\text { Brigade }\end{array}$ & A55 & $\begin{array}{l}\text { Iraqi Hezbollah } \\
\text { Brigade }\end{array}$ & A90 & ISA \\
\hline A21 & $\begin{array}{l}\text { Egyptian } \\
\text { Mujahideen }\end{array}$ & A56 & mujahideen & A91 & Allah's army \\
\hline A22 & Jihad and Unity & A57 & Al-Qaida in Jordan & A92 & $\begin{array}{c}\text { Liberation of the eagle } \\
\text { of Kurdistan }\end{array}$ \\
\hline A23 & $\begin{array}{c}\text { Muslim } \\
\text { Brotherhood }\end{array}$ & A58 & $\begin{array}{l}\text { Islamic Combatant } \\
\text { Group Tunisia } \\
\end{array}$ & A93 & $\begin{array}{l}\text { Kurdish Treh } \\
\text { Hazadiyeh }\end{array}$ \\
\hline
\end{tabular}

\begin{tabular}{|c|c|c|c|c|c|}
\hline A23 & $\begin{array}{c}\text { Muslim } \\
\text { Brotherithood }\end{array}$ & A58 & \begin{tabular}{|c|} 
Islamic Combatant \\
Group Tunisa
\end{tabular} & A93 & $\begin{array}{l}\text { Kurdish Treh } \\
\text { Hazadyeh }\end{array}$ \\
\hline A24 & $\begin{array}{c}\begin{array}{c}\text { Supponters of } \\
\text { Jerusslem }\end{array} \\
\end{array}$ & A59 & $\begin{array}{c}\text { Supporters of Stariah } \\
\text { in Tunisia }\end{array}$ & A 9 & $\begin{array}{l}\text { Union of Revolutionany } \\
\text { Communists of Turkey }\end{array}$ \\
\hline A25 & Herbollah & $A 60$ & $\begin{array}{l}\text { Noroctan Islamic } \\
\text { Combatant Group } \\
\end{array}$ & A95 & Ergnet hole \\
\hline A26 & Fatah al-ssam & $A 61$ & $\begin{array}{l}\text { Inhertance of the } \\
\text { Mujijhideen }\end{array}$ & $A 96$ & Gray Wolves \\
\hline A27 & Ansar Alliance & A 62 & Ansar Menci & A97 & $\begin{array}{l}\text { Mojahedin-e Khalq } \\
\text { Organizztion of Iran } \\
\end{array}$ \\
\hline A28 & $\begin{array}{l}\text { Zayed Geraha } \\
\text { detachnent }\end{array}$ & A63 & \begin{tabular}{|c|} 
Ansar al-Ilsam in the \\
Muslim Desest
\end{tabular} & A98 & $\begin{array}{c}\text { Alrmighty God's } \\
\text { Brigade }\end{array}$ \\
\hline A29 & \begin{tabular}{|c|}
$\begin{array}{c}\text { Liberation of } \mathrm{Al}- \\
\text { Sham }\end{array}$ \\
\end{tabular} & A 64 & $\begin{array}{l}\text { Young Illarnic } \\
\text { Fighting Group }\end{array}$ & A99 & Kurdish Free Life Patty \\
\hline A30 & Khorassan Network & $\mathrm{A} 65$ & LFG & $A 100$ & \begin{tabular}{|c|c|} 
Iranian Pegeple's radda \\
Guerrilas
\end{tabular} \\
\hline A31 & Sharm Free People & $A 66$ & \begin{tabular}{|c|c}
$\begin{array}{c}\text { Libyan branch of the } \\
\text { Islamic State }\end{array}$ \\
\end{tabular} & A101 & \begin{tabular}{|c|} 
Democratic Front for \\
the Arab Prople of \\
Ahrva
\end{tabular} \\
\hline A32 & Islamic State & A 67 & $\begin{array}{c}\text { Salafist Organaization } \\
\text { for Mission and } \\
\text { Combat in Mauniazania }\end{array}$ & A102 & $\begin{array}{l}\text { Awas Arab Ba' th } \\
\text { Party }\end{array}$ \\
\hline $\mathrm{A}^{3} 3$ & Hezbollah Brigades & A68 & $\begin{array}{l}\text { Al-Qvida in the } \\
\text { Islamic Maghreb }\end{array}$ & A103 & $\begin{array}{l}\begin{array}{l}\text { Tripoli Youth } \\
\text { Novement }\end{array} \\
\end{array}$ \\
\hline \begin{tabular}{|l|l|}
$A 34$ \\
\end{tabular} & Ansar al-slam & A69 & $A Q A P$ & & \\
\hline A35 & $\begin{array}{l}\text { Mchammedan } \\
\text { army }\end{array}$ & A70 & IAA & & \\
\hline
\end{tabular}

Figure 1 List of terrorist organizations.

Use B1, B2... B17 for the 17 Middle Eastern countries of Palestine, Egypt and Iraq, numbered as follows.

\begin{tabular}{|c|c|c|c|c|c|}
\hline Code & Country & Code & Country & Code & Country \\
\hline B1 & Palestine & B7 & Tunisia & B13 & Kuwait \\
\hline B2 & Egypt & B8 & Morocco & B14 & Bahrain \\
\hline B3 & Lebanon & B9 & Libyan & B15 & Israeli \\
\hline B4 & Syria & B10 & Mauritania & B16 & Turkey \\
\hline B5 & Iraq & B11 & Yemeni & B17 & Iranian \\
\hline B6 & Jordanian & B12 & Saudi Arabia & & \\
\hline
\end{tabular}

Figure 2 Middle East country code.

\subsection{Building Relationship Matrices and Network Models}

Combining Figures 1 and 2, the matrix and network model of "organization-organization" and "organization-area of activity" relationships in the Middle East are constructed.

\begin{tabular}{|c|c|c|c|c|c|c|c|c|}
\hline & $\mathrm{A} 1$ & $\mathrm{~A} 2$ & $\mathrm{~A} 3$ & $\mathrm{~A} 4$ & $\cdots$ & $\mathrm{A} 101$ & $\mathrm{~A} 102$ & $\mathrm{~A} 103$ \\
\hline $\mathrm{A} 1$ & 1 & 1 & 0 & 0 & $\cdots$ & 0 & 0 & 0 \\
\hline $\mathrm{A} 2$ & 1 & 1 & 0 & 0 & $\cdots$ & 0 & 0 & 0 \\
\hline $\mathrm{A} 3$ & 0 & 0 & 1 & 1 & $\cdots$ & 0 & 0 & 0 \\
\hline $\mathrm{A} 4$ & 0 & 0 & 1 & 1 & $\cdots$ & 0 & 0 & 0 \\
\hline$\cdots$ & $\cdots$ & $\cdots$ & $\cdots$ & $\cdots$ & $\cdots$ & $\cdots$ & $\cdots$ & $\cdots$ \\
\hline $\mathrm{A} 101$ & 0 & 0 & 0 & 0 & $\cdots$ & 1 & 1 & 0 \\
\hline $\mathrm{A} 102$ & 0 & 0 & 0 & 0 & $\cdots$ & 1 & 1 & 0 \\
\hline $\mathrm{A} 103$ & 0 & 0 & 0 & 0 & $\cdots$ & 0 & 0 & 1 \\
\hline
\end{tabular}

Figure 3 Organizational-organizational.

\begin{tabular}{|c|c|c|c|c|c|c|c|c|}
\hline & B1 & B2 & B3 & B4 & $\cdots$ & B15 & B16 & B17 \\
\hline A1 & 1 & 0 & 0 & 0 & $\cdots$ & 1 & 0 & 0 \\
\hline A2 & 1 & 0 & 1 & 0 & $\cdots$ & 1 & 0 & 0 \\
\hline A3 & 1 & 0 & 1 & 0 & $\cdots$ & 1 & 0 & 0 \\
\hline A4 & 1 & 0 & 1 & 0 & $\cdots$ & 1 & 0 & 0 \\
\hline A5 & 1 & 0 & 1 & 0 & $\cdots$ & 0 & 1 & 0 \\
\hline$\cdots$ & $\cdots$ & $\cdots$ & $\cdots$ & $\cdots$ & $\cdots$ & $\cdots$ & $\cdots$ & $\cdots$ \\
\hline A101 & 0 & 0 & 0 & 0 & $\cdots$ & 0 & 0 & 1 \\
\hline A102 & 0 & 0 & 0 & 0 & $\cdots$ & 0 & 0 & 1 \\
\hline A103 & 0 & 0 & 0 & 0 & $\cdots$ & 0 & 0 & 0 \\
\hline
\end{tabular}

Figure 4 Organizational-territorial.

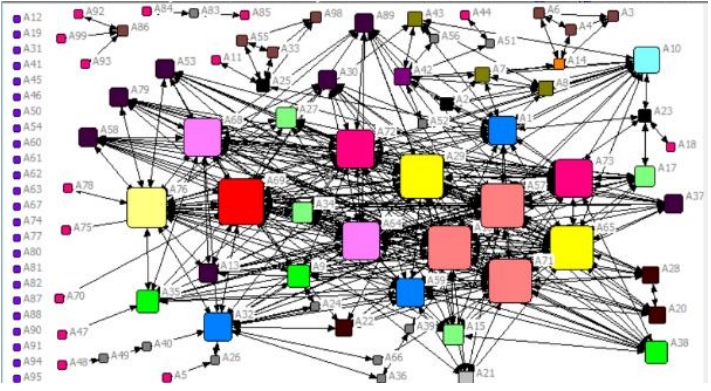

Figure 5 Organization - Organizational.

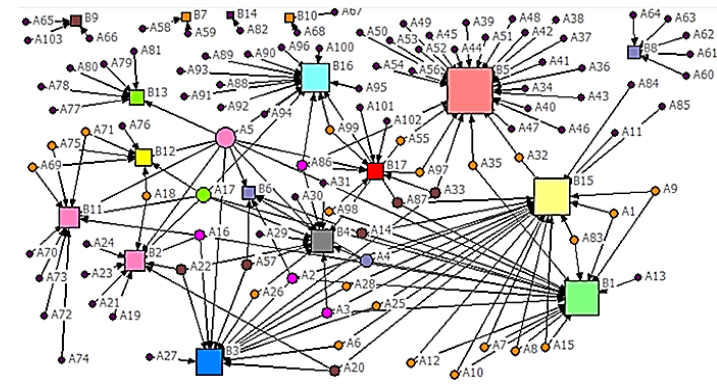

Figure 6 Organization - area of activity.

It can be seen that the organizational relationship network mainly consists of three sub-networks centered on A83, A86 and A69, of which the sub-network centered on A69 is the largest; and the centrality of B5 in the activity area relationship network is the largest, it means that it is in the core position of the network.

\section{ANALYSIS OF THE NETWORK OF TERRORIST ORGANIZATIONS IN THE MIDDLE EAST}

\subsection{Centrality Analysis}

Centrality is an indicator used to describe the importance of actors in a network and is divided into: point, middle and near-centrality [6]. If a terrorist organization has a high degree of centrality, it is considered to have direct links to many organizations; if 


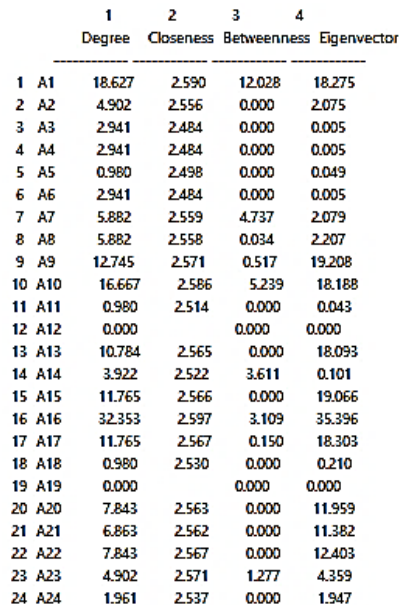
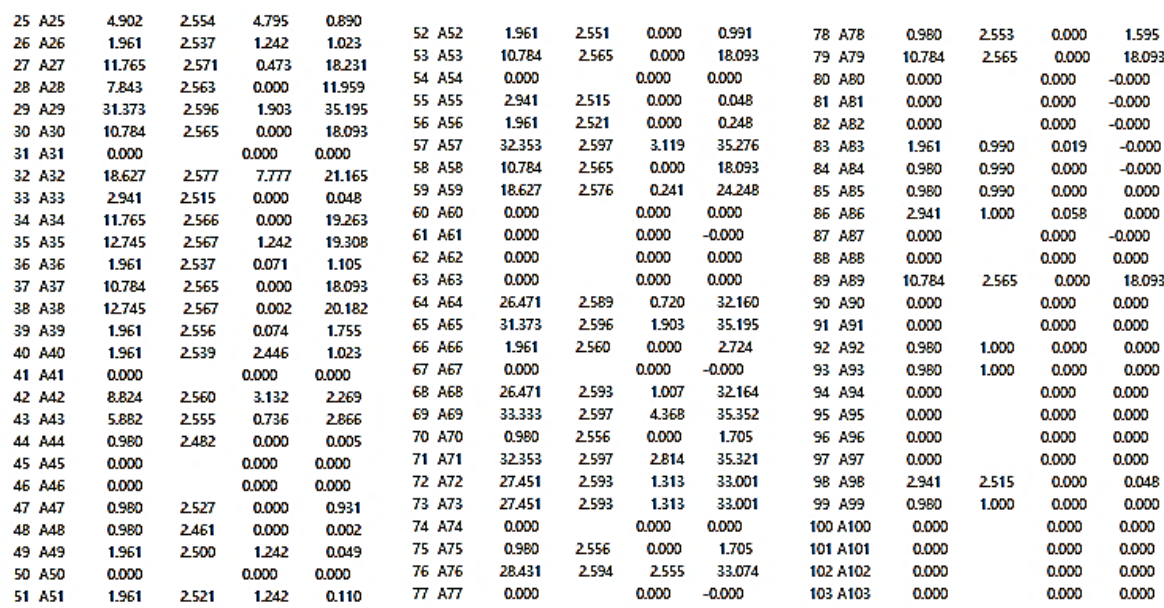

Figure 7 Centrality of "organization-organization" relationship networks.

\begin{tabular}{|c|c|c|c|c|c|c|c|c|c|c|c|c|c|c|c|}
\hline \multirow{2}{*}{\multicolumn{4}{|c|}{ Degree Closeness Betweenne }} & \multirow{3}{*}{$\begin{array}{l}A 26 \\
A 27 \\
A 28\end{array}$} & \multirow{3}{*}{$\begin{array}{l}0.118 \\
0.059 \\
0.118\end{array}$} & \multirow{3}{*}{$\begin{array}{l}0.631 \\
0.607 \\
0.662\end{array}$} & \multirow{3}{*}{$\begin{array}{l}0.001 \\
0.000 \\
0.002\end{array}$} & \multirow{3}{*}{$\begin{array}{l}\text { A } 52 \\
\text { A53 } \\
\text { A54 }\end{array}$} & \multirow{2}{*}{$\begin{array}{l}0.059 \\
0.059\end{array}$} & \multirow{2}{*}{$\begin{array}{l}0.576 \\
0.576\end{array}$} & \multirow{2}{*}{$\begin{array}{l}0.000 \\
0.000\end{array}$} & \multirow{2}{*}{$\begin{array}{l}\text { A78 } \\
\text { A79 }\end{array}$} & \multirow{2}{*}{$\begin{array}{l}0.059 \\
0.059\end{array}$} & \multirow{2}{*}{$\begin{array}{l}0.509 \\
0.509\end{array}$} & \multirow{2}{*}{$\begin{array}{l}0.000 \\
0.000\end{array}$} \\
\hline & & & & & & & & & & & & & & & \\
\hline A1 & 0.118 & 0.658 & 0.001 & & & & & & 0.059 & 0.576 & 0.000 & AED & 0.059 & 0.509 & 0.000 \\
\hline$A 2$ & 0.235 & afEE & 0 & A.29 & 0.059 & 0.601 & 0.000 & A55 & 0.118 & 0.699 & 0.024 & AB1 & 0.059 & 0.509 & 2000 \\
\hline A3 & 235 & a.70B & 0.01 & A30 & 0.059 & 0.601 & 0.000 & A56 & 0.059 & 0.576 & 0.000 & AB2 & 2059 & 221.000 & 0.000 \\
\hline A4 & 294 & 0.713 & 0.01 & A31 & 1.059 & 0.601 & 1000 & A 57 & 0.176 & 0.639 & 0.002 & AB3 & 118 & 0.658 & .001 \\
\hline A5 & $58 \mathrm{~B}$ & 0.906 & c & A32 & 0.118 & 0.674 & 2042 & $A 5 B$ & 0.059 & 73.667 & 0.000 & AB4 & 2059 & 0.570 & 2000 \\
\hline A6 & 118 & 0.662 & c & A33 & 0.176 & 0.737 & 2048 & A59 & 0.059 & 73.667 & 0.000 & A85 & 2.059 & 0.570 & 2000 \\
\hline A7 & 118 & a.65B & 0 & A34 & 0.059 & .576 & 2000 & $A \in D$ & 0.059 & 24.556 & 0.000 & A86 & 235 & 0.784 & 1098 \\
\hline AB & 118 & 0.65 & $\circ$ & A35 & 0.118 & 0.737 & 0.043 & A61 & 059 & 4.556 & 0.000 & ABT & 0.176 & 0.713 & 2.024 \\
\hline A9 & 0.118 & a.65B & 0.0 & A36 & 0.059 & 1.576 & 2.000 & A62 & 0.059 & 24.556 & 0.000 & ABB & 1059 & 2.610 & 2000 \\
\hline A10 & & & & A37 & 0.059 & 0.576 & 0.000 & A63 & 0.059 & 24.556 & 0.000 & AB9 & .059 & 1610 & 2000 \\
\hline A11 & 0.059 & 0.570 & 0.0 & $A 3 B$ & 0.059 & 0.576 & 0.000 & AE4 & .059 & 24.556 & 0.000 & ASO & 2.059 & 2610 & .000 \\
\hline A12 & 0.118 & 0.6 & a. & A39 & 0.059 & 0.576 & 0.000 & A65 & 0.059 & 44.200 & 0.000 & A91 & 2.059 & 1610 & 1000 \\
\hline A13 & 0.059 & $0 \in 24$ & 0.0 & A4O & 0.059 & 0.576 & 0.000 & A66 & 0.059 & 44.200 & 0.000 & A92 & 0.059 & 0.610 & 2.000 \\
\hline A14 & a.13 & & & A41 & 0.059 & 0.576 & 0.000 & $A \in 7$ & 0.059 & 73.668 & 0.000 & A93 & 0.059 & 0.610 & 0.000 \\
\hline $\begin{array}{l}\text { A15 } \\
\text { A16 }\end{array}$ & $\begin{array}{l}a-1 \\
0 .\end{array}$ & & & A42 & 0.059 & 0.576 & 0.000 & $A 6 B$ & 0.059 & 73.667 & 0.000 & A94 & 0.059 & 0.610 & 0.000 \\
\hline A17 & 0.353 & 0.795 & & A43 & 0.059 & 0.576 & 0.000 & A69 & 0.118 & 0.526 & 0.000 & A95 & 0.059 & 0.610 & 0.000 \\
\hline A18 & 0.118 & 0.544 & ac & A44 & 0.059 & 0.576 & 0.000 & A70 & 0.059 & 0.519 & 0.000 & A96 & 0.059 & 0.610 & 0.000 \\
\hline A19 & 0.059 & 0.531 & 0.000 & A45 & 0.059 & 0.576 & 0.000 & A71 & 0.118 & 0.526 & 0.000 & A97 & 0.118 & 0.678 & 0.012 \\
\hline $\mathrm{A} 2 \mathrm{O}$ & 0.176 & $\alpha 691$ & 0.013 & A46 & 0.059 & 0.576 & 0.000 & A72 & 0.059 & 0.519 & 0.000 & ASB & 0.118 & 0.650 & 0.004 \\
\hline A 21 & 0.059 & 0.531 & 0.0 & A47 & 0.059 & 1576 & 0.000 & A73 & 0.059 & 0.519 & 0.000 & A99 & 0.118 & 0.631 & 0.003 \\
\hline$A 22$ & Q.13 & 0.654 & & A4B & 0.059 & 0.576 & 0.000 & A74 & 59 & 0.519 & 0.000 & A100 & 0.059 & 0.610 & 0.000 \\
\hline A 23 & 0 & 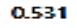 & & A49 & & & 0.000 & A] & 0.118 & 0.5 & 0.000 & & 0.059 & 0.576 & 0.000 \\
\hline 24 & & 0.531 & & A50 & 0.059 & 0.576 & 0.000 & A76 & 0.059 & 0.512 & 0.000 & A102 & 0.059 & 0.576 & 0.000 \\
\hline 23 & 0.118 & $a_{662}$ & 0.002 & A51 & 0.059 & 0.576 & 0.000 & $R / /$ & 0 & 0.509 & 0.000 & A103 & 0.059 & 44.200 & 0.000 \\
\hline
\end{tabular}

Figure 8 Terrorist organization centrality of the "Organization-Area of Operation" network.

the intermediate centrality is high, the terrorist organization is considered to be important; and if the proximity centrality is high, it is likely to be at the center of the network [5, 7]. Using the Centrality function to calculate the centrality of the network of "organization-organization" and "organization-area of activity" relationships in the Middle East, the results are as follows.

The diagram shows that A69, A57, A71, A76, and A16 are core organizations with high degrees and proximity to the center and relatively low degrees and proximity to the center, while A1 and A32 have high degrees and proximity to the center and relatively low degrees and are key nodes in determining whether other terrorist organizations can be linked.

A5 has the highest punctuality and centrality and a low proximity to centrality, indicating that it is active in multiple countries but is not a core organization, while A58, A59, A67 and A68 have the highest proximity to centrality and very low punctuality and centrality, indicating that it is at the center of the network.

\begin{tabular}{|c|c|c|c|}
\hline B1 & 0.84 & 0.531 & 0144 \\
\hline 82 & Dost & 0.427 & 0052 \\
\hline B.3 & a136 & 0.511 & DOBB \\
\hline 84 & 0113 & 0.504 & a.103 \\
\hline 85 & 0262 & 0.475 & $O \geq 81$ \\
\hline$B E$ & 0049 & 0.414 & Dods \\
\hline B 7 & 0019 & 65.500 & Dodo \\
\hline BS & 0049 & 27.000 & 0.001 \\
\hline B9 & 0029 & 45000 & Dodo \\
\hline B10 & Dors & 65.500 & Dod \\
\hline B11 & Doss & 0414 & aors \\
\hline B12 & Does & D.4DS & Dose \\
\hline 813 & 0058 & 0.404 & aoro \\
\hline 814 & Doto & 135.000 & 0,000 \\
\hline 815 & 0204 & 0469 & alds \\
\hline 816 & 0.46 & 0.515 & 0100 \\
\hline 817 & aors & 0435 & aоro \\
\hline
\end{tabular}

Figure 9 Regional centrality of the "Organization-Area of Activity" network.

In general, with the exception of some terrorist organizations, there is little difference in the degree of centrality of the areas in which they operate, indicating there is a clear trend towards the globalization of terrorist activities.

\subsection{Network Density Analysis}

Density reflects the closeness of the relationships between the components. To calculate the density of the 
network, first should calculate the shortcut distance of each point. After calculating the shortcut distance of the network centered on A69, organizations with a shortcut distance of no more than 2 to the core organization (degree centrality $\geq 32$ ) are selected to build a relationship matrix and calculate their average distance, cohesion index and network density. The results are as follows.

\begin{tabular}{|c|c|c|c|}
\hline $\begin{array}{c}\text { Core } \\
\text { organization }\end{array}$ & $\begin{array}{c}\text { Average } \\
\text { distance }\end{array}$ & $\begin{array}{c}\text { Cohesion } \\
\text { index }\end{array}$ & $\begin{array}{c}\text { Network } \\
\text { density }\end{array}$ \\
\hline A16 & 2.351 & 0.262 & 0.1011 \\
\hline A57 & 2.359 & 0.257 & 0.1004 \\
\hline A69 & 2.312 & 0.269 & 0.1131 \\
\hline A71 & 2.312 & 0.269 & 0.1131 \\
\hline
\end{tabular}

Figure 10 Table of values for three indexs.

In terms of overall values, the cohesion index and network density of the four networks are low, suggesting an increasingly broad and loosely globalized approach to terrorist relationships.

\section{COUNTER-TERRORISM SITUATION AND RESPONSES}

\subsection{Features of Terrorist Organizations}

First, the terrorist organization structure is networked. As we can see from the visualization model in Figure 5, the structure of terrorist organizations is transformed from a vertical structure into a non-central, flexible network structure[8], with scattered branches and members, no unified leadership, fighting on their own, flexible actions and strong organizational planning ability, which brings certain interference to our search for key leading organizations when analyzing the relationship network of terrorist organizations.

Second, the globalization of terrorist organizations' activities. According to the results of regional centrality and network density analysis, the links between terrorist organizations are no longer limited by countries and regions, and the transnational nature is getting stronger and stronger. This also leads to the strengthening of the concealment of terrorist organizations, which brings great difficulty to intelligence collection [9].

Third, the motives of terrorist organizations are diversified. The traditional terrorist organizations have clear political ideas and specific political goals, but the motives of terrorist organizations to create terrorist incidents are sometimes purely retaliatory, without clear political goals, and the targets of attacks have a tendency to be random and non-selective.

\subsection{Counter-terrorism Response}

First, we must strengthen international counter-terrorism cooperation. Terrorism is global in nature and threatens the security and development of all countries. Therefore, it is necessary to strengthen international counter-terrorism cooperation, cut off terrorist organizations' foreign financial sources and foreign aid channels, reduce their operating space, and carry out intelligence exchanges and technical cooperation with international organizations and other countries to combat terrorist activities [10].

Second, overall planning of the fight against terrorism. The issue of terrorism involves all aspects of national security. Therefore, the fight against terrorism must be planned as a systematic project. To achieve economic prosperity, to resolutely oppose linking the spearhead to a certain nationality, and to prevent terrorist forces from using religion for reactionary propaganda and agitation [1].

Third, to establish an international political and democratic system. In order to reform the international political and economic order, it is necessary to take measures to correct the root causes, consult on political equality and seek mutual benefit in the economic field, and seek to establish appropriate mechanisms to eliminate existing contradictions so as to promote the process of world democratization [11].

\section{CONCLUSION}

In this paper, the network of terrorist organizations in the Middle East is studied according to the social network analysis method. Then using UCINET to analyze their network density and centrality. The experimental results show that the characteristics of terrorist organizations derived from the study are consistent with reality, indicating that the method is more reliable in the field of counter-terrorism.

\section{ACKNOWLEDGMENTS}

This work is supported by the Natural Science Basic Research Plan in Shanxi Province of China (No.2020JM-361), the Young and middle-aged scientific research backbone projects of Engineering University of PAP (No.KYGG201905) and the basic research foundation project of Engineering University of PAP (No.WJY201920, No.WJY202019), military theory research project of Engineering University of PAP (No.JLY2020085), education and teaching fund project of Engineering University of PAP (No.WJJ202039), the PAP's Military Scientific Research Mandatory Project (No.WJ2020A020047, No.WJ2020A020048, No.WJ2020A020049).

\section{REFERENCES}

[1] Yang Hui, A new theory of counter-terrorism, Beijing: World Knowledge Press, 2005.

[2] Liu Jun, Introduction to Social Network Analysis, Social Science Literature Press, 2004. 
[3] Valdis E. Krebs, Mapping Networks of Terrorist Cells, CONNECTIONS, 24(3):43-52.2002. [EB/OL].

[4] Zhang Hai, A study on the covert network of terrorist organizations based on social network theory, Hunan: Graduate School of National University of Defense Technology, 2010:1-20.

[5] Ji Zhiye, Feng Zhongping, Fu Xiaoqiang, Yearbook of International Terrorism and the Fight against Terrorism, Beijing: Current Affairs Press, 2017.

[6] Liu Jun, Integral Network Analysis Handout: A Practical Guide to UCINET Software, Shanghai: Shanghai People's Publishing House, 2009.
[7] Yao Jianlong, Zhou Zhou Zhou, Introduction to Counter-Terrorism, Beijing: Peking University Press, 2018.

[8] XING-XING CHEN, ZHAO-YANG LU, YAO ZHAO, Study on the Space-Time Characteristics of Domestic Terrorist Activities Based on Social Network Analysis, 2018

[9] Bruce W. Dearstyne, Fighting terrorism, making war: Critical insights in the management of information and intelligence, 2005, 22(2):170-186.

[10] Wang Qi, Tian Yiming, GTD data analysis of global terrorist activities and China's countermeasures, Crime Research, 2018(2).

[11] Qian Xuewen, Middle East Terrorism Studies, Shanghai: Current Affairs Press, 2013. 